\title{
Influences of Different Milk Yields of Holstein Cows on Milk Quality Indicators in the Czech Republic
}

\section{JANU゚, O. HANUŠ, J. FRELICH ${ }^{1}$, A. MACEK², I. ZAJÍČKOVÁ, V. GENČUROVÁ, R. JEDELSKÁ}

\author{
Research Institute for Cattle Breeding, Rapotín, Czech Republic \\ ${ }^{1}$ South Bohemia University, Agronomical Faculty, České Budějovice, Czech Republic \\ ${ }^{2}$ Agrovýzkum Rapotín, Czech Republic
}

Received September 5, 2005

Accepted October 11, 2007

\begin{abstract}
Janů L., O. Hanuš, J. Frelich, A. Macek, I. Zajíčková, V. Genčurová, R. Jedelská: Influences of Different Milk Yields of Holstein Cows on Milk Quality Indicators in the Czech Republic. Acta Vet. Brno 2007, 76: 553-561.

The milk yield (MY) is an important economic and health factor closely connected with the health status of dairy cows, their reproduction performance, longevity and milk composition and properties (MIs). The differences within MIs between high yielding herd (Group 1; $10282 \mathrm{~kg}$ per lactation) and three herds with average MY (Group 2; $7926 \mathrm{~kg}$ ) were tested. The files with 96 and 290 milk samples were collected in summer and winter feeding seasons and well balanced in lactation factors. Group 1 had higher genetical value, better nutrition and was milked three times per day and its MY was higher by $30 \%(P<0.001)$. Among 23 milk indicators (MIs) under study only a few MIs $(30.4 \%)$ were influenced $(P<0.05)$ : somatic cell count (SCC); urea $(\mathrm{U})$; acetone (AC); $\mathrm{pH}$ acidity; alcohol stability; curd firmness; the ratio of urea nitrogen in non-protein nitrogen (URN). Except for U, these changes were less important. Protein spectrum was not affected $(P>0.05)$. The $\mathrm{U}$ was probably higher due to higher loading of the nitrogen nutrition $(4.27>$ $\left.3.57 \mathrm{mmol} \cdot \mathrm{l}^{-1}\right)$ in MY 1. Surprisingly, SCC was higher $\left(112>8110^{3} \cdot \mathrm{ml}^{-1}\right)$ and AC lower $((0.0374)$ $\left.0.0250<(0.0577) 0.0336 \mathrm{mmol}^{-1} \mathrm{1}^{-1}\right)$ in Group 1. Both the MIs did not indicate problems of the health status. An indicator of energy nutrition balance as fat/protein ratio was not influenced (1.15 \pm 0.24 versus $1.16 \pm 0.23 ; P>0.05)$, despite the large difference between MY 1 and 2 . URN was higher in MY $1(46.5>39.1 \%)$ due to more efficient nutrition, like in U. The high MY had no negative impacts on MIs with well balanced nutrition of Holstein cattle.
\end{abstract}

Dairy cow, Holstein cattle, milk yield, milk composition, milk properties, health status indicators

In dairy cattle, genetic improvement and well balanced nutrition are the main factors improving the milk yield (MY). Furthermore, feeding technology may help to fully exploit the genetic potential as evidenced in current Holstein $(\mathrm{H})$ population. In general, a better use of these factors in dairy herds may enhance the lactation physiology and also the composition and milk properties of high yielding cows. The resistance degree to health disorders (e. g. mastitis) or stress may increase as well. These facts are interesting for milk producers, veterinarians and dairy operations because of impacts on farmer milk price, processing efficiency and product quality. Relevant changes are observed due to routine performance of milk recording in dairy herds. However, it is only possible for a limited number of milk indicators such as MY, fat, protein, lactose and urea contents and somatic cell counts. These are usually included in milk recording and dairy herd improvement programmes. Of course, interesting changes could be found in other milk components and properties as well. The genetic and nutritional improvements are in accordance with the basic equation phenotype $=$ genotype + environment the main factors of cow MY increase. However, high MY is often a reason for breeder fears from its possible negative consequences. It could cause production health disorders as a result of impaired immunity decrease of cows including a shorter production age of dairy cows. Poor reproduction

Address for correspondence:

Ing. Libor Janů

Research Institute for Cattle Breeding, Rapotín

Výzkumníků 267

78813 Vikýřovice

Czech Republic
Phone: +420583392155

Fax: +420 583392129

E-mail: libor.janu@vuchs.cz

http://www.vuchs.cz

http://www.vfu.cz/acta-vet/actavet.htm 
performance and longevity of cows was reported due to nutritional protein over-loading of their metabolism during a longer period to reach a high MY. It was linked with high urea contents in their body liquids (Piatkowski et al. 1981; Ropstad and Refsdal 1987; Butler et al. 1996; Říha and Hanuš 1999ab; Hlásný 2000; Hanuš et al. 2001). During the last fifteen years the population structure of dairy cows has sharply changed in the Czech Republic. Holstein cattle forms $44.9 \%$ of the national herd (equal to 163.5 thousand animals). An increase by $9.6 \%$ (since 1998) despite the decrease of the total number of dairy cows by $63 \%$ has been recorded since 1989 (Kvapilík 2002; Kvapilík and Střeleček 2003; Kvapilík et al. 2002, 2003 and 2004; Kvapilík and Hanuš 2004; Motyčka 2004; Bucek et al. 2004). The average lactation MY of H breed increased from $5648 \mathrm{~kg}$ (1998) up to $7303 \mathrm{~kg}$, i.e. by $29.3 \%$ within five years. However, at the same time the number of pregnancies decreased and longevity of dairy cows deteriorated markedly. Some of the above authors also reported an increasing risk of production disorders in the population. Therefore studies on influences of the MY increase on milk quality of cows, their health status and milk quality are becoming more and more important (Sawa and Piwczynski 2002; Ayadi et al. 2003; Remond et al. 2004; Junqueira et al. 2005). The strategy of the genetic improvement of longevity has been included in the breeding programme of breed with higher efficiency (Motyčka 2004).

This study is aimed at the assessment of possible effects of a high MY of Holstein cows on milk composition and properties and also at the importance of possible changes for processing technology and on milk health status indicators for production disorders. The evaluation was carried out by comparisons on a larger list of milk indicators (MIs) than is currently known (e. g. in the bulk sample analyses for the payment according to raw milk quality or in the individual sample analyses for milk recording purposes; Suchánek and Hanuš 1997; Kvapilík et al. 2002, 2003 and 2004; Kvapilík and Hanuš 2004; Motyčka 2004). We compared high and average milk yielding cows during a longer period. We were thus able to obtain information on possible trends and results of genetic improvement programmes of dairy herds in terms of total quality of milk and its acceptability as raw material for milk food chain.

\section{Materials and Methods}

The individual milk samples were collected from 4 various herds of Holstein $(H)$ dairy cows during 3 experimental years. The animals were selected at random, but with a higher MY in the herd and with respect to the number and stage of lactation that were balanced with the real profile of herd. The samples were collected during summer (A, S) and winter (F, M) months. All animals were fed supplements of concentrate mixture according to MY and standard demands. The feeding rations consisted of roughage: grass silage + corn silage + GPS (silage) from cereals (herd 1); alfalfa silage + corn silage (herd 2); clover silage + corn silage (herd 3 and 4 ); hence the feeding was not the same in all herds. It was one of the reasons why the MY of herd 1 was higher along with a $100 \%$ proportion of $\mathrm{H}$ blood. Herds 2, 3 and 4 had $89 \%$ of Holstein blood only. Three daily milkings system was used in herd 1 and two milkings in other herds. Herd 1 was kept at the altitude $550 \mathrm{~m}$, herd 2 at $215 \mathrm{~m}, 3$ at 570 $\mathrm{m}$ and 4 at $300 \mathrm{~m}$. Milk samples were free of preservatives and/or preserved (with bronopol, 0.04\%) after cooling transport $\left(<10^{\circ} \mathrm{C}\right)$. The investigation was aimed at the following milk indicators: DMY daily milk yield ( $\mathrm{kg}$ of milk/day); FAT fat $\left(\mathrm{g} \cdot 100 \mathrm{~g}^{-1}\right)$; LAC lactose (monohydrate; $\left.\mathrm{g} \cdot 100 \mathrm{~g}^{-1}\right)$; SNF solids non fat $\left(\mathrm{g} \cdot 100 \mathrm{~g}^{-1}\right)$; SCC somatic cell count $\left(10^{3} \cdot \mathrm{ml}^{-1}\right)$; U urea $\left(\mathrm{mmol}^{-1} \mathrm{l}^{-1}\right)$; AC acetone $\left(\mathrm{mmol} \cdot \mathrm{l}^{-1}\right) ; \mathrm{pH}$ acidity; $\mathrm{C}$ electrical conductivity $\left(\mathrm{mS} \cdot \mathrm{cm}^{-1}\right)$; AL alcohol stability (in $\mathrm{ml}$ ); $\mathrm{SH}$ titratable acidity (in $\mathrm{ml} 0.25 \mathrm{~mol} \cdot \mathrm{l}^{-1} \mathrm{NaOH}$ solution, used to titration of 100 $\mathrm{ml}$ of milk); TEC time for enzymatic coagulation (in seconds); RCQ subjective estimation of the rennet curds quality (in classes); RCF rennet curds firmness (in $\mathrm{mm}$ ); WV whey volume (in $\mathrm{ml}$ ); CP crude protein (Kjeldahl total $\mathrm{N} \times 6.38 ; \mathrm{g} \cdot 100 \mathrm{~g}^{-1}$ ); CAS casein (casein $\left.\mathrm{N} \times 6.38 ; \mathrm{g} \cdot 100 \mathrm{~g}^{-1}\right)$; TP true protein (protein $\left.\mathrm{N} \times 6.38 ; \mathrm{g} \cdot 100 \mathrm{~g}^{-1}\right)$; WP whey protein (difference TP-CAS; $\cdot \mathrm{g}^{\left.-100 \mathrm{~g}^{-1}\right)}$; NPN non protein nitrogen $\left(\mathrm{CP}-\mathrm{TP}\right.$ nitrogen $\left.\times 6.38 ; \mathrm{g} \cdot 100 \mathrm{~g}^{-1}\right)$; URN urea nitrogen/non protein nitrogen ratio (\%); F/CP fat/crude protein ratio. The casein numbers on the basis of crude and true protein were in \% (CN-CP, CN-TP). DMY was measured by the Tru-Test flow meters. AL was determined using milk titration ( $5 \mathrm{ml}$ of milk) and $96 \%$ ethanol until visible milk protein flakes occurred. Some of the indicators for cheese-making were measured according to the own standards: TEC from addition of Renilase (microbial enzyme) to visible milk protein coagulation; RCF in $\mathrm{mm}$ in contrary sense to real firmness value, the more mm the poorer curds firmness; RCQ as subjective estimation of rennet curds quality (1 excellent, 4 poor); WV as volume of the whey at rennet precipitation. The milk indicator differences between group averages 
with high (1 herd) and average (2 herds 2, 3 and 4) MYs were investigated. Group 1 included 96 and group 2 included 290 individual milk samples. The groups were well-balanced regarding the relevant seasonal influences and in terms of lactation stage and quite balanced in terms of lactation number. Statistical characteristics were calculated: arithmetical average (x), geometrical mean (xg), standard deviation (sd), variation coefficient (vx, $\%), t$-values for significance assessing of the differences (Excel). The SCC (in $10^{3} \cdot \mathrm{ml}^{-1}$ ) and AC (in mg $\cdot l^{-1}$ ) were transformed on logarithmic scale (Ali and Shook 1980; Shook 1982; Hanuš et al. 1995, 1999 and 2001abc). The data files are presented in figures by the box graphs with the following construction rules: the file median (the central short horizontal line); the top edge of $1^{\text {st }}$ and $3^{\text {rd }}$ quartile (the tetragon); the variation range as difference between maximum and minimum (the vertical line).

\section{Results and Discussion}

High milk yield of herd 1 corresponds with the average MY of a cow on standard lactation (305 days) of $10282 \mathrm{~kg}$, as opposed to $7926 \mathrm{~kg}$ in the other herds with average MY (Table 1). The average DMY in Group 1 was by $30 \%$ higher than in Group 2 and this high difference was significant $(P \leq 0.001$; Table 1 and Fig. 1 , DMY). The average stage of lactation (SL) of cows did not differ between groups $(P \geq 0.05$; Table 1), $153 \pm 85$ and $147 \pm 85$ lactation days. However, the average lactation number (NL) was different $(P \leq 0.01$; Table 1), $2.7 \pm$ 1.3 and $2.3 \pm 1.3$ lactations. As known, more significant effect on milk indicators is caused more by the lactation stage than by the parity number. In addition, the difference between lactation numbers is significant, but owing to its value ( 0.38 lactation), the possibility of an influence on milk composition and properties is negligible. The studied high MY factor (reached by a higher level of whole cow rearing in Group 1, e. g. by more effective nutrition and triple day milkings; Remond et al. 2004; Ayadi et al. 2003), did have an effect $(P \leq 0.05$ and $P \leq 0.001$; Table 1; Fig. 1$)$ on the following milk indicators (MIs): somatic cell count (SCC); urea (U); acetone (AC); pH; alcohol stability (AL); RCF; URN. The other 16 MIs (FAT, LAC, SNF, C, SH, TEC, RCQ, WV, CP, CAS, TP, WP, NPN, F/CP, CN-CP, $\mathrm{CN}-\mathrm{TP})$ were influenced non-significantly $(P \geq 0.05$; Table 1$)$. Thus most of the important MIs were not negatively affected by the breeding programme within the $\mathrm{H}$ breed, which is linked with factors such as a higher degree of genetic improvement, higher milking frequency and more efficient nutrition to better exploit the genetic potential of the animals. Of the significantly influenced MIs (30.4\%) due to high MY and the fact that only the less important MIs (from the technology point of view) are included among them means that $\mathrm{H}$ cows are probably not very susceptible to the MY effect (in terms of possible modifications of their total lactation physiology in dependence on MY level), their milk composition and property changes. URN as a relative indicator was significantly influenced (Table 1; Fig. 1 , URN, $P \leq 0.001)$. The cows with high MY had higher URN than the cows with average MY $(46.5 \%>39.1 \%)$. It is in accordance with higher $U$ in milk of high yielding cows. Johnson and Young (2003) reported that U nitrogen in milk decreased with increasing $\mathrm{CP}$ and increases with higher MY in $\mathrm{H}$ and Jersey cows. Our results are in accordance with theirs. However, this is probably without a significant practical impact. More detailed studies of milk composition of various cattle breeds were performed by Suchánek and Gajdůšek (1991) and Hanuš and Foltys (1991). A significant breed influence was confirmed especially for the nitrogen phase of milk. Former Black Pied Lowland breed showed lower CP and TP (3.15 g·100g $\mathrm{g}^{-1}$ and $\left.2.98 \mathrm{~g} \cdot 100 \mathrm{~g}^{-1}\right)$ and also CAS (2.36 g.100 g $\left.\mathrm{g}^{-1}\right)$ compared with Bohemian Spotted cattle (BS). A reverse situation was only in WP $(0.62$ $\left.\mathrm{g} \cdot 100 \mathrm{~g}^{-1}\right)$. The same tendency was in the mineral composition of milk; e.g., lower values were observed in $\mathrm{Ca}$ and $\mathrm{P}$ contents $\left(116\right.$ and $\left.84 \mathrm{mg} \cdot 100 \mathrm{~g}^{-1}\right)$. These have close relationships to findings in protein complex. The current situation in $\mathrm{H}$ breed is somewhat different. It is likely that with the increase of MY in all breeds the actual breed differences in main milk components disappear. For example, former difference (Black Pied Lowland breed) CP was about $-0.20 \mathrm{~g} \cdot 100 \mathrm{~g}^{-1}$ compared to BS. In the recent study it was only $-0.10 \mathrm{~g} \cdot 100 \mathrm{~g}^{-1}$ under comparable keeping and nutrition conditions in the identical herd of $\mathrm{H}$ and BS (Hanuš et 
Table 1. Significance of the differences in milk chemical components, health indicators and physical and technological properties between H cows with high (1) and average (2) MY

\begin{tabular}{|c|c|c|c|c|c|c|c|c|}
\hline & \multicolumn{3}{|c|}{1} & \multicolumn{3}{|c|}{2} & \multirow[b]{2}{*}{$t$} & \multirow[b]{2}{*}{ sign. } \\
\hline & $\mathrm{x} \pm \mathrm{sd}$ & $\mathrm{Vx} \%$ & $\mathrm{xg}$ & $\mathrm{x} \pm \mathrm{sd}$ & $\mathrm{vX} \%$ & $\mathrm{xg}$ & & \\
\hline $\mathrm{n}$ & \multicolumn{3}{|c|}{96} & \multicolumn{3}{|c|}{290} & & \\
\hline NL & $2.72 \pm 1.271$ & 46.728 & & $2.34 \pm 1.346$ & 57.521 & & 2.42 & $*$ \\
\hline SL & $152.77 \pm 85.055$ & 55.675 & & $146.84 \pm 84.721$ & 57.696 & & 0.59 & ns \\
\hline DMY & $33.71 \pm 8.029$ & 23.818 & & $25.99 \pm 6.858$ & 26.387 & & 9.12 & $* * *$ \\
\hline FAT & $3.74 \pm 0.740$ & 19.792 & & $3.76 \pm 0.791$ & 21.008 & & 0.32 & ns \\
\hline LAC & $5.01 \pm 0.157$ & 3.134 & & $4.98 \pm 0.233$ & 4.679 & & 1.17 & ns \\
\hline SNF & $8.79 \pm 0.33$ & 3.754 & & $8.75 \pm 0.389$ & 4.446 & & 0.90 & ns \\
\hline SCC & $375.84 \pm 740.882$ & 197.127 & & $201.17 \pm 426.141$ & 211.831 & & 2.83 & $* *$ \\
\hline $\log \mathrm{SCC}$ & $2.0493 \pm 0.6284$ & 30.634 & 112 & $1.9133 \pm 0.5286$ & 27.696 & 81 & 2.14 & $*$ \\
\hline $\mathrm{U}$ & $4.265 \pm 1.066$ & 24.994 & & $3.565 \pm 1.881$ & 52.772 & & 3.46 & $* * *$ \\
\hline $\mathrm{AC}$ & $0.0374 \pm 0.0334$ & 89.355 & & $0.0577 \pm 0.0979$ & 169.791 & & 1.99 & $*$ \\
\hline $\log \mathrm{AC}$ & $0.1638 \pm 0.4976$ & 311.25 & 0.0250 & $0.2852 \pm 0.4735$ & 163.103 & 0.0336 & 2.30 & $*$ \\
\hline $\mathrm{pH}$ & $6.77 \pm 0.124$ & 1.832 & & $6.74 \pm 0.129$ & 1.914 & & 1.99 & $*$ \\
\hline $\mathrm{C}$ & $4.43 \pm 0.416$ & 9.391 & & $4.35 \pm 0.513$ & 11.793 & & 1.38 & ns \\
\hline $\mathrm{AL}$ & $1.77 \pm 1.273$ & 71.921 & & $1.47 \pm 0.928$ & 63.129 & & 2.48 & $*$ \\
\hline $\mathrm{SH}$ & $7.27 \pm 1.094$ & 15.048 & & $7.36 \pm 0.874$ & 11.875 & & 0.82 & ns \\
\hline TEC & $112.71 \pm 51.368$ & 45.575 & & $119.42 \pm 59.979$ & 50.225 & & 0.98 & ns \\
\hline RCQ & $2.81 \pm 0.944$ & 33.594 & & $2.74 \pm 0.91$ & 33.212 & & 0.65 & ns \\
\hline $\mathrm{RCF}$ & $17.28 \pm 1.862$ & 10.775 & & $16.39 \pm 3.619$ & 22.081 & & 2.30 & $*$ \\
\hline WV & $35.19 \pm 3.793$ & 10.779 & & $35.32 \pm 3.606$ & 10.21 & & 0.30 & ns \\
\hline $\mathrm{CP}$ & $3.25 \pm 0.316$ & 9.723 & & $3.23 \pm 0.336$ & 10.402 & & 0.51 & $\mathrm{~ns}$ \\
\hline CAS & $2.58 \pm 0.276$ & 10.698 & & $2.56 \pm 0.286$ & 11.172 & & 0.60 & $\mathrm{~ns}$ \\
\hline $\mathrm{TP}$ & $3.07 \pm 0.301$ & 9.805 & & $3.06 \pm 0.316$ & 10.327 & & 0.27 & $\mathrm{~ns}$ \\
\hline WP & $0.49 \pm 0.09$ & 18.367 & & $0.5 \pm 0.09$ & 18.0 & & 0.94 & ns \\
\hline NPN & $0.18 \pm 0.079$ & 43.889 & & $0.17 \pm 0.064$ & 37.647 & & 1.24 & ns \\
\hline URN & $46.52 \pm 16.066$ & 34.536 & & $39.09 \pm 16.648$ & 42.589 & & 3.81 & $* * *$ \\
\hline $\mathrm{F} / \mathrm{CP}$ & $1.15 \pm 0.243$ & 21.130 & & $1.16 \pm 0.227$ & 19.569 & & 0.35 & $\mathrm{~ns}$ \\
\hline $\mathrm{CN}-\mathrm{CP}$ & $79.45 \pm 3.112$ & 3.917 & & $79.42 \pm 2.965$ & 3.733 & & 0.08 & $\mathrm{~ns}$ \\
\hline CN-TP & $84.08 \pm 2.734$ & 3.252 & & $83.73 \pm 2.639$ & 3.152 & & 1.11 & ns \\
\hline
\end{tabular}

Statistical significance of the difference: $\mathrm{ns}=P>0.05 ; *=P \leq 0.05 ; * *=P \leq 0.01 ; * * *=P \leq 0.001$; $\mathrm{n}=$ number of animals; $\mathrm{x} \pm \mathrm{sd}=$ arithmetic mean \pm standard deviation; $\mathrm{xg}=$ geometric mean $t=$ test criterion of $t$-test; sign. $=$ significance of the difference.

NL number of lactations; SL stage of lactation; DMY daily milk yield; FAT fat; LAC lactose; SNF solids non fat; SCC somatic cell count; U urea; AC acetone; $\mathrm{pH}$ acidity; $\mathrm{C}$ electrical conductivity; AL alcohol stability; $\mathrm{SH}$ titratable acidity; TEC time for enzymatic coagulation; RCQ rennet curds quality; RCF rennet curds firmness; WV whey volume; CP crude protein; CAS casein; TP true protein; WP whey protein; NPN non protein nitrogen; $\mathrm{URN}$ urea nitrogen/non protein nitrogen ratio; F/CP fat/crude protein ratio; $\mathrm{CN}-\mathrm{CP}$ and $\mathrm{CN}-\mathrm{TP}$ casein numbers.

al. 2003). An increasing trend was recorded in the casein number (Hanuš et al. 1995, 82.6\% $<84.1$ and $83.7 \%$ in this work). Regarding energy metabolism principles (Andersson and Lundström 1984; Andersson 1984, 1988; Andersson and Emanuelson 1985; Gravert et al. 1986; Diekmann 1987; Gustafsson and Emanuelson 1993; Illek and Pechová 1997; Geishauser et al. 1997, 1998; Pechová et al. 2000; Kirchnerová et al. 2001; Chládek et al. 2002) it was surprising that $\mathrm{F}$ had not been significantly influenced by the different MY. The same situation was for CP, TP and CAS. It confirmed the relatively high stability of the lactation physiology of $\mathrm{H}$ cows against the high MY effects.

The RCF, AL as indirect markers of thermostability and $\mathrm{pH}$ were affected (Table 1; Fig. 1 ; all indicators $P \leq 0.05)$. The difference in $\mathrm{pH}$ was negligible. The cows with higher MY 

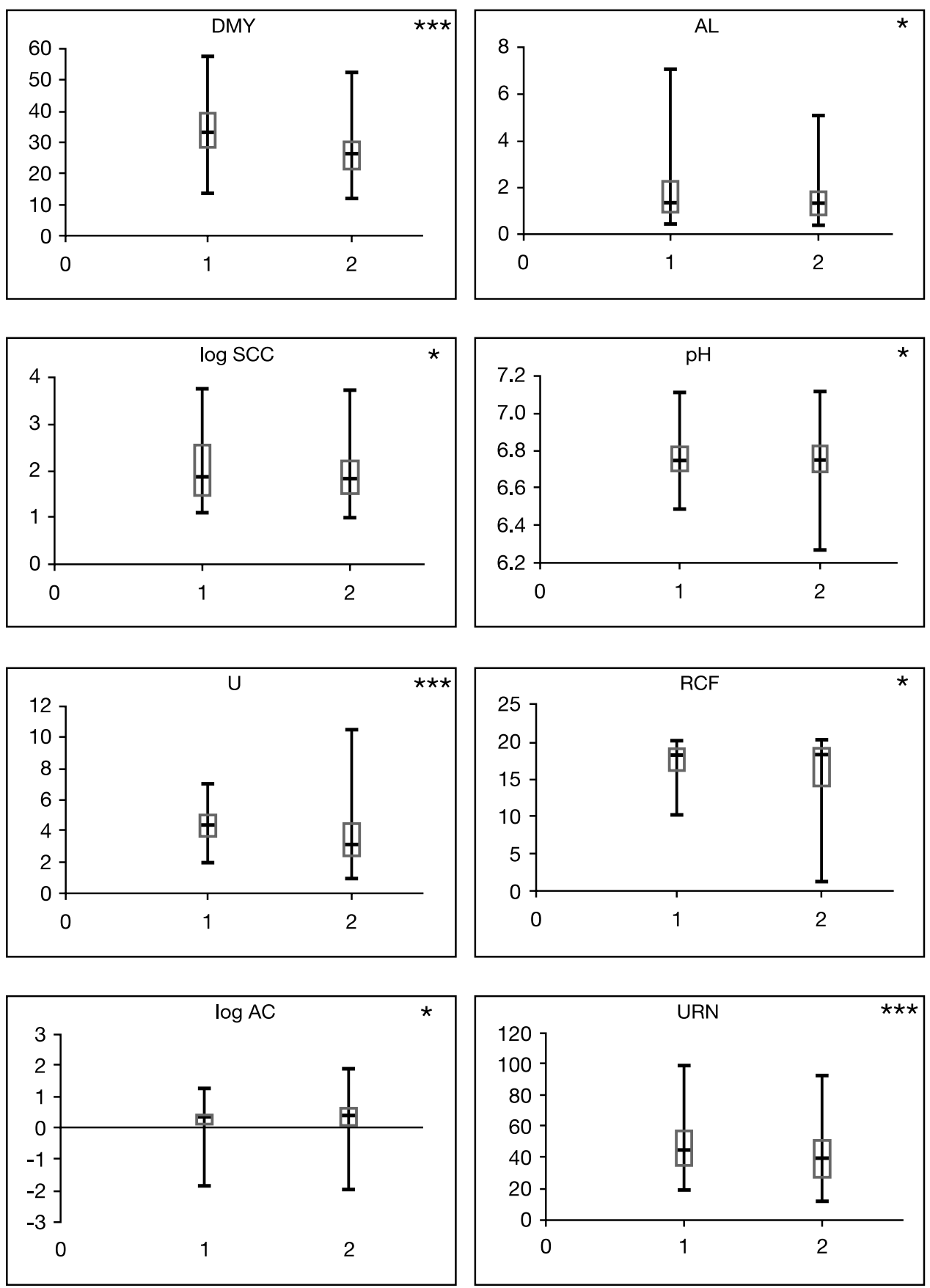

Fig. 1. Presentation of the main central statistical moments and characteristics of data frequency distribution for the cases of significant differences in the MQIs between H cows with high (1) and average (2) MY.

Construction of box graph: the file median (the central short horizontal line); the top edge of $1^{\text {st }}$ and $3^{\text {rd }}$ quartile (the tetragon); the variation range as difference between maximum and minimum (the vertical line). 
exhibited slightly higher (better) AL of proteins probably due to better nutrition, but they also exhibited slightly lower RCF. The impacts on the technological properties could not be considered as practically important. Regarding the health indicators of milk, SCC (Table 1; Fig. 1; $P \leq 0.01), \mathrm{U}(P \leq 0.001)$ and AC $(P \leq 0.05)$ were influenced. The SCC trend shows higher values connected with higher MY and surprisingly with higher frequency of milking $\left(11210^{3} \cdot \mathrm{ml}^{-1}>8110^{3} \cdot \mathrm{ml}^{-1}\right)$. This result needs not be a rule because the SCC values are considerably influenced by various farm conditions, such as the selenium supplements in the animal nutrition (Foltys and Kirchnerová 2001). In addition, with the increase of MY the approach to cattle breeding procedures is changing. Motyčka (2004) reported on the importance increase of the production function signs including cows' health status and longevity markers in breeding models of the $\mathrm{H}$ populations. The $\mathrm{U}$ was higher in the milk from cows with more intensive nutrition and high MY $\left(4.27 \mathrm{mmol} \cdot 1^{-1}>3.57 \mathrm{mmol} \cdot 1^{-1}\right)$. According to current knowledge of nitrogen metabolism in dairy cows (Kirchgessner et al. 1985, 1986; Hanuš et al. 1993; Illek and Pechová 1997; Pechová et al. 2000; Johnson and Young 2003; Kučera 2003), it can be expected that animals with high MY may suffer from a higher nitrogen over-loading of their organs and tissues very often. This condition may negatively affect their pregnancy and longevity (Piatkowski et al. 1981; Butler et al. 1996; Ropstad and Refsdal 1987; Ŕíha and Hanuš 1999ab; Hlásný 2000; Hanuš et al. 2001a). AC as energy metabolism indicator was surprisingly lower in high MY cows ((0.0374) $\left.0.0250 \mathrm{mmol}^{-1} \mathrm{l}^{-1}<(0.0577) 0.0336 \mathrm{mmol} \cdot \mathrm{l}^{-1}\right)$. It demonstrates that a higher risk of a severe negative energy balance in the cows in high MY (Gravert et al. 1986; Geishauser et al. 1997, 1998; Diekmann 1987; Andersson 1984, 1988; Andersson and Lundström 1984ab; Andersson and Emanuelson 1985) can be prevented by well-balanced nutrition. Geometric means of AC ( 0.0250 and 0.0336 $\mathrm{mmol} \cdot \mathrm{l}^{-1}$ ) were lower as previously $1992-1996$ (Hanuš et al. 1999). At that time MY was lower and $\mathrm{AC}$ varied from 0.0560 to $0.1054 \mathrm{mmol} \cdot \mathrm{l}^{-1}$ (xg with higher values in winter). It demonstrates a favourable influence of better balanced nutrition on the cows' health state despite increasing MY. Gustafsson and Emanuelson (1993) reported much higher AC (a newly revised AC level in milk for subclinical ketosis, hyperketonaemia, respectively, was derived as value $>0.6887 \mathrm{mmol} \cdot \cdot^{-1}$ ) as still safe for ketosis occurrence in comparison with other studies. Probably subclinical ketosis was not very frequent in our data set. That may be why our AC findings were in the opposite trend compared with the results of the mentioned papers. This could have been caused by feeding the so-called ketogenic roughage, e.g. silages of deteriorated quality in the MY group 2 as well. These facts may mean that $\mathrm{H}$ cows are less susceptible to MY level than to nutrition source quality. Certain risks of high MY were found only for the higher SCC and U. The increased milk U should not be overlooked. It could cause impaired values of important economic indicators such as the reproduction performance level and production age. Nevertheless, not a higher U (4.27 $\mathrm{mmol} \cdot \mathrm{l}^{-1}$; Table 1) is increased with the possibility of causing a negative physiological impact. Regarding the principles of the energy and nitrogen metabolism (Andersson 1984, 1988; Kirchgessner et al. 1985, 1986; Gravert et al. 1986; Diekmann 1987; Jagoš et al. 1991; Gustafsson and Emanuelson 1993; Hanuš et al. 1993, 1999; Illek and Pechová 1997; Pechová et al. 2000; Johnson and Young 2003; Kučera 2003) it was interesting that the F/CP ratio was not significantly influenced by a different MY of H cows $(1.15 \pm$ 0.24 versus $1.16 \pm 0.23 ; P>0.05)$ despite the large difference between the compared MY levels. The F/CP ratio is a good indicator of energy metabolism of cows and cheese-making ability of milk, too (Agabriel et al. 1990, 1991; Bíro et al. 1992; Schulz 1997; Hanuš et al. 2003). That is why the $\mathrm{F} / \mathrm{CP}$ ratio is in good correlation $(0.33 ; P<0.001)$ with milk $\mathrm{AC}$ (Hanuš et al. 2004). Therefore the mentioned finding is surprising. Nevertheless, it again confirms a lower susceptibility of the whole lactation physiology of $\mathrm{H}$ cows to the impact of high MY, as already mentioned above. 
The high MY reached by the genetic improvement of animals, by their more efficient nutrition and by three milkings per day, does not result in impaired quality of raw milk, provided the physiological needs of cows are fully satisfied. The $\mathrm{H}$ cows were not susceptible to the effect of a high MY on their milk composition and properties. Their relatively high stability was confirmed. Nevertheless, possible negative impacts of too high MY on the cows' reproductive performance, immune system and longevity were not investigated.

\section{Vlivy dvou různých úrovní produkce mléka holštýnských krav na ukazatele kvality mléka v České republice}

Mléčná užitkovost (M) je významný ekonomický a zdravotní faktor. M ovlivňuje zdravotní stav dojnic, jejich reprodukci, dlouhověkost a složení a vlastnosti mléka (MU). Byly testovány rozdíly uvnitř MU mezi vysoce užitkovým stádem $(1 ; 10282 \mathrm{~kg}$ za laktaci) a třemi stády s průměrnou M $(2 ; 7926 \mathrm{~kg})$. Soubory s 96 a 290 vzorky mléka byly odebírány v letním a zimním krmném období a byly dobře vyváženy s ohledem na faktory laktace. Skupina 1 byla na vyšší genetické úrovni, měla lepší výživu a byla dojena třikrát denně. Její $M$ byla vyšší o $30 \%(P<0,001)$. Bylo vyšetřováno 23 mléčných ukazatelů (MU). Pouze několik MU $(30,4 \% ; 7 \mathrm{z} 23)$ bylo ovlivněno $(P<0,05)$ : počet somatických buněk (SCC); močovina (U); aceton (AC); pH kyslost; alkoholová stabilita; pevnost sýřeniny; poměr močovinového dusíku v nebílkovinném dusíku (URN). S výjimkou U byly tyto změny méně významné. Proteinové spektrum nebylo ovlivněno $(P>0,05)$. U byla u M 1 vyšší pravděpodobně pro vyšší zatížení výživy dusíkem $\left(4,27>3,57 \mathrm{mmol} \cdot 1^{-}\right.$ $\left.{ }^{1}\right)$. SCC byl ve skupině 1 překvapivě vyšší $\left(112>8110^{3} \cdot \mathrm{ml}^{-1}\right)$ a AC nižší $((0,0374) 0,0250$ $\left.<(0,0577) 0,0336 \mathrm{mmol} \cdot \mathrm{l}^{-1}\right)$. Oba MU nenaznačovaly na problémy zdravotního stavu. Poměr tuk/bílkoviny jako ukazatel vyrovnanosti energetické výživy nebyl ovlivněn $(1,15 \pm 0,24$ versus $1,16 \pm 0,23 ; P>0,05)$ navzdory velkému rozdílu mezi M 1 a 2 . U M 1 byl vyšší URN $(46,5 \%$ $>39,1 \%$ ) v důsledku intenzívnější výživy podobně jako u U. Vysoká M nemusí mít negativní dopady na MU při dobře vyvážené výživě holštýnského skotu.

\section{Acknowledgements}

The study was supported by projects 1G46086 and MSM 6007665806 and also by activities of the NRL-RM.

\section{References}

AGABRIEL C, COULON JB, MARTHY G, CHENEAU N 1990: Facteurs de variation du taux protéique du lait de vache. INRA Prod Anim 2: 137-150

AGABRIEL C, COULON JB, MARTHY G 1991: Facteurs de variations du rapport des teneurs en matiéres grasses et ptotéiques du lait de vache. INRA Prod Anim 2: 141-149

ALI AKA, SHOOK GE 1980: An optimum transformation for somatic cells concentration in milk. J Dairy Sci 63: $487-490$

ANDERSSON L 1984: Concentrations of blood and milk ketone bodies, blood isopropanol and plasma glucose in dairy cows in relation to the degree of hyperketonaemia and clinical signs. Zbl Vet Med A 31: 683-693

ANDERSSON L 1985: Subclinical ketosis in dairy cows. Veterinary Clinical of North America: Food Anim Pract 2: 233-251

ANDERSSON L, EMANUELSON U 1985: An epidemiological study of hyperketonaemia in Swedish dairy cows: determinants and the relation to fertility. Prev Vet Med 3: 449

ANDERSSON L, LUNDSTRÖM K 1984a: Effect of energy balance on plasma glucose and ketone bodies in blood and milk and influence of hyperketonaemia on milk production of postparturient dairy cows. Zbl Vet Med 31: 539-547

ANDERSSON L, LUNDSTRÖM K 1984b: Milk and blood ketone bodies, blood isopropanol and plasma glucose in dairy cows, methodical studies and diurnal variations. Zbl Vet Med 31: 340-349

AYADI M, CAJA G, SUCH X, KNIGHT CH 2003: Effect of omitting one milking weekly on lactation performances and morphological udder changes in dairy cows. J Dairy Sci 86: 2352-2358

BÍRO D, LABUDA J, CABADAJOVÁ M 1992: Factors influencing cow milk production and fat to protein content ratio. (In Slovak) Živoč Výr 6-7, 37: 521-528 
BUCEK P, PYTLOUN P, PYTLOUN J 2004: The actual state of the cattle milk recording in the CR. (In Czech) Sborník VÚCHS Rapotín, Moderní postupy v kontrole užitkovosti skotu jako základ úspěšného šlechtění, ISBN 80-903142-3-6: 2-14

BUTLER WR, CALAMAN JJ, BEAM SW 1996: Plasma and milk urea nitrogen in relation to pregnancy rate in lactating dairy cattle. J Anim Sci 74: 858-865

DIEKMANN L 1987: Energiebilanz vor und nach dem Kalben. Tierzüchter 2: 72-73

FOLTYS V, KIRCHNEROVÁ K 2001: Improvement of health status in milk cows and decrease of somatic cell counts in milk by feeding the organic selenium. (In Slovak) J Farm Anim Sci XXXIV: 229-235

GEISHAUSER T, LESLIE KE, DUFFIELD T, EDGE V 1997: An evaluation of milk ketone tests for the prediction of left displaced abomasum in dairy cows. J Dairy Sci 80: $3188-3192$

GEISHAUSER T, LESLIE KE, DUFFIELD T, SANDALS D, EDGE V 1998: The association between selected metabolic parameters and left abomasal displacement in dairy cows. J Vet Med A 45: 499-511

GRAVERT HO, LANGER R, DIEKMANN L, PABST K, SCHULTE-COERNE H 1986: Ketonkörper in Milch als Indikatoren für die Energiebilanz der Milchkühe. Züchtungskunde 58: 309-318

GUSTAFSSON AH, EMANUELSON U 1993: Milk acetone as indicator of hyperketonaemia in dairy cows - the critical value revised. EAAP Congress, Aarhus, Denmark, p. 443

HANUŠ O, FOLTYS V 1991: Some characteristics and mineral components of milk of cattle breeds kept in Czechoslovakia. (In Czech) Živoč Výr 36: 497-505

HANUŠ O, ŽVÁČKOVÁ I, GENČUROVÁ V, GABRIEL B 1992: A relationship between milk lactose content and indicators of the mammary gland health in the first third of lactation. (In Czech) Vet Med (Praha) 37: 595-604

HANUŠ O, GENČUROVÁ V, FICNAR J, GABRIEL B, ŽVÁČKOVÁ I 1993: The relationship of urea and protein in bulk milk to some breeding factors. Živoč Výr 38: 61-72

HANUŠ O, GAJDU゚ŠEK S, BEBER K, FICNAR J, JEDELSKÁ R 1995: Composition and technological properties of milk from dairy cows in the middle stage of lactation and their interrelationships. (In Czech) Živoč Výr 40: 555-561

HANUŠ O, TICHÁČEK A, KOPECKÝ J 1995: Interpretation of SCC values determined in milk samples of individual cows. (In Czech) Mliekarstvo 1, 26: 16-19

HANUŠ O, SKYVA J, FICNAR J, JÍLEK M, TICHÁČEK A, JEDELSKÁ R, DOLÍNKOVÁ A 1999: A note to interpretation procedures of results ketone and acetone contents evaluation (Ketotest) in individual cow's milk samples. (In Czech) Výzkum v chovu skotu 4, XLI, 148: 17-34

HANUŠ O, TRAJLINEK J, HLÁSNÝ J, GENČUROVÁ V, KOPECKÝ J, JEDELSKÁ R 2001: Ketosis problem, its diagnostic and monitoring. (In Czech) In Rearing and breeding of cattle for competitionable production: proceedings of the seminar VÚCHS Rapotín: b, 105-113

HANUŠ O, KVAPILÍK J, KLOPČIČ M, BJELKA M 2001a: Important components of nitrogen phase of milk and breeder's factors. (In Czech) In Chov a šlechtění skotu pro konkurenceschopnou výrobu: sborník referátů VÚCHS Rapotín, pp. 114-121

HANUŠ O, BJELKA M, TICHÁČEK A, JEDELSKÁ R, KOPECKÝ J 2001c: Substantiation and usefulness of transformations in data sets of analyzed milk parameters. (In Czech) In Rearing and breeding of cattle for competitionable production: proceedings of the seminar VÚCHS Rapotín: 122-135

HANUŠ O, FRELICH J, ROUBAL P, VORLÍČEK Z, ŘIIHA J, POZDÍŠEK J, BJELKA M 2003: Dairy cow breed impacts on some chemical-compositional, physical, health and technological milk parameters. (In Czech) Výzkum v chovu skotu 4, XLV, 164: 1-10

HANUŠ O, FRELICH J, KRON V, ŘÍHA J, POZDÍŠEK J 2004: The checking of the body condition score, health state and nutrition of dairy cows and improvement of their reproduction functions. (In Czech) Zemědělské informace, UZPI Praha, ISBN 80-7271-146-6

HLÁSNÝ J 2000: The effect of ketosis complicated by acidose or uremia on dairy cow pregnancy. (In Czech) Výzkum v chovu skotu 151: 18-28

CHLÁDEK G, MÁCHAL L, VANĚK D, 2002: Blood plasma glucose and its relationship with milk production and reproduction parameters in Holstein cows. Výzkum v chovu skotu 158: 1-8

ILLEK J, PECHOVÁ A 1997: The dairy cow metabolism disorders and milk quality. (In Czech) Farmáŕ 6: 29-30

JAGOŠ P, ILLEK J, SUCHÝ P 1991: Beziehungen zwischen Störungen im Energiestoffwechsel und der Milchzusammensetzung. Mh Vet-Med 46: 698-699

JOHNSON RG, YOUNG AJ 2003: The association between milk urea nitrogen and DHI production variables in western commercial dairy herds. J Dairy Sci 86: 3008-3015

JUNQUEIRA FS, MADALENA FE, REIS GL 2005: Production and economic comparison of milking F-1 Holstein $\times$ Gir cows with and without the stimulus of the calf. Livestock Prod Sci 97: 241-252

KIRCHGESSNER M, KREUZER M, ROTH MAIER DORA A 1986: Milk urea and protein content to diagnose energy and protein malnutrition of dairy cows. Arch Anim Nutr 36: 192-197

KIRCHGESSNER M, ROTH MAIER DORA A, RÖHRMOSER G 1985: Harnstoffgehalt in Milch von Kühen mit Energie- bzw. Proteinmangel und anschliessender Realimentation. Z Tierphysiol Tiernähr Futtermkde 53: 264-270 
KIRCHNEROVÁ K, VALENT M, PETRIKOVIČ P, PAJTÁŠ M, FOLTYS V 2001: Effect of intensity and technique of feeding of precalving dairy cows on incidence of ketobodies and glycaemia after calving. (In Slovak) J Farm Anim Sci XXXIV: 123-131

KUČERA J 2003: Relationships between milk urea content, milk yield and milk composition in Holstein cows. Výzkum v chovu skotu 161: 1-6

KVAPILÍK J 2002: Cattle farming in the Czech Republic before and after entry in the European Union. Report of Research Institute for Animal Production, Prague, p. 22

KVAPILÍK J, HANUŠ O 2004: Country report of the Czech Republic - structural and farm developments as consequence of the introduction of milk quota and suckler cow and beef premiums. EAAP and FAO Workshop: Farm Management and Extension Needs in CEC under the EU Milk Quota System, Bled, Slovenia, September $4^{\text {th }}$

KVAPILÍK J, PYTLOUN J, BUCEK P 2002, 2003, 2004: Annual Report, 2001, 2002, 2003. Cattle Breeding in the Czech Republic. (In Czech) ČMSCH, a.s., Praha, p.103, p. 110, p. 104

KVAPILÍK J, STŘELEČEK F 2003: Cattle and sheep quotas negotiated between the Czech Republic and the EU. Czech J Anim Sci 11, 48: 487-498

MOTYČKA J 2004: The direction of the Holstein breed genetical improvement. (In Czech) Sborník VÚCHS Rapotín, Moderní postupy v kontrole užitkovosti skotu jako základ úspěšného šlechtění, ISBN 80-903142-3-6: 35-43

PECHOVÁ A, ILLEK J, PAVLATA L 2000: The factors which are influencing fat concentration in cow milk. (In Czech) Veterinářství 50: 238-241

PIATKOWSKI B, VOIGT J, GIRSCHEWSKI H 1981: Einfluss des Rohproteinniveaus auf die Fruchtbarkeit und den Harnstoffgehalt in Körperflüssigkeiten bei Hochleistungskühen. Arch Tierernähr 31: 497-504

REMOND B, POMIES D, DUPONT D, CHILLIARD Y 2004: Once-a-day milking of multiparous Holstein cows throughout the entire lactation: milk yield and composition, and nutritional status. Anim Res 53: 201-212

ROPSTAD E, REFSDAL AO 1987: Herd reproductive performance related to urea concentration in bulk milk. Acta Vet Scand 28: 55-63

ŘÍHA J, HANUŠ O 1999a: The relationships between pregnancy parameters of dairy cow herds and metabolical and compositional parameters in bulk milk samples. (In Czech) Výzkum v chovu skotu 146: 1-6

ŘíHA J, HANUŠ O 1999b: The relationships between individual reproduction parameters and milk composition in first 120 lactation days. (In Czech) Výzkum v chovu skotu 148: 3-17

SAWA A, PIWCZYNSKI D 2002: Somatic cell count and milk yield and composition in White $\times$ HolsteinFriesian cows. Med Weter 8 28: 636-640

SHOOK GE 1982: Approaches to summarizing somatic cell count which improve interpretability. Nat. Mast. Council, Louisville, Kentucky, pp. 1-17

SCHULZ T 1997: Ohne Formeln und Tabellen die Leistung gesteigert. Top Agrar 5: 20-22

SUCHÁNEK B, GAJDƯŠEK S 1991: Milk composition in the cattle breeds in the CSFR. (In Czech) Živoč Výr 36: $289-296$

SUCHÁNEK B, HANUŠ O 1997: Bulk milk sample composition in the area of one dairy factory. (In Czech) Výzkum v chovu skotu 140: 21-25 
